\title{
Long-term effects of pediatric extracorporeal shockwave lithotripsy on renal function
}

This article was published in the following Dove Press journal:

Research and Reports in Urology

28 April 2014

Number of times this article has been viewed

\author{
Yigit Akin' \\ Selcuk Yucel ${ }^{2}$ \\ 'Department of Urology, Harran \\ University School of Medicine, \\ Sanliurfa, Turkey; ${ }^{2}$ Department of \\ Urology, Acibadem University School \\ of Medicine, Istanbul, Turkey
}

Introduction: Extracorporeal shock wave lithotripsy (ESWL) is a well-known and successful treatment modality. In addition, it can be used in premature infants. ESWL is used to treat kidney and ureter stones in children. However, although it is a preferred noninvasive treatment in that setting, there is debate about its long-term effects on growing kidneys in children.

Objectives: To investigate the long-term effects of pediatric ESWL on renal function in light of updated literature.

Methods: PubMed and Medline were searched for studies on ESWL in a pediatric population with keywords including efficacy, child, kidney calculi, ureter calculi, lithotripsy, injury, vascular trauma, and shock waves. The research was limited to the English literature during a period from 1980 to 2014 . In total, 3,000 articles were evaluated, but only 151 papers were considered. Only the manuscripts directly related to the reviewed subjects were included in the current study.

Results: However, the acute effects of ESWL in kidney are well-described. Although there are limited studies on the long-term effects of ESWL in children, there is a widespread opinion that ESWL is not affecting renal functions in the long-term.

Conclusion: ESWL is a safe, effective, and noninvasive treatment option in children. Although ESWL can cause some acute effects in the kidney, there is no long-term effect on the growing kidneys of children.

Keywords: child, lithotripsy, nephrolithiasis, renal injury, vascular trauma

\section{Introduction}

Since extra corporeal shock wave lithotripsy (ESWL) was introduced, noninvasive treatment of urinary stone disease jumped an age. ${ }^{1}$ After these developments, Newman et al reported successful results of ESWL in the pediatric population. ${ }^{2}$ The incidence of urolithiasis in the pediatric age group is $2 \%-3 \%$ of all stone diseases. ${ }^{3}$ However, pediatric stone disease is endemic in Turkey, Pakistan, and some South Asian, African, and South American countries. ${ }^{4}$ Recently, ESWL has been used worldwide with wellknown advantages such as its high efficiency and ease of use in children. ${ }^{5}$

Both of the mechanical and dynamic effects in ESWL consist of effective stone fragmentation. However, the cavitation effect is the most important effect of ESWL, with shear and spalling effects being the other parts of the mechanism. Cavitation bubble collapse is responsible for stone fragmentation, which can create destructive forces. There are published reports in the literature that these effects of ESWL also can harm thin-walled vessels and surrounding kidney tissues. ${ }^{6,7}$ These acute effects cause hemorrhage, release some cytokines/inflammatory cellular mediators, and cause infiltration of
Correspondence: Yigit Akin

Department of Urology, Harran University School of Medicine, Yenisehir, Kampus, 63100 Sanliurfa, Turkey

Tel +904143183000

$\mathrm{Fax}+904143183005$

Email yigitakin@yahoo.com 
tissues by inflammatory response cells, which result in welldefined short-term complications. Animal studies have proved these adverse effects of ESWL in kidneys. ${ }^{8,9}$ In addition, these studies showed histological changes in glomerular epithelium and interstitial cells, as well as an apoptotic effect on renal tubular cells. ${ }^{8,9}$ However, ESWL has not caused long-term renal lesions identifiable by a dimercaptosuccinic acid renal scan up to now. ${ }^{10}$ Goel et al reported there was not significant functional differentiation measured by the glomerular filtration rate (GFR) of the growing kidney. ${ }^{11}$ The ESWL treatment has well-defined acute effects in kidney, although published reports showed normal GFR and scintigraphy. On the basis of these conflicting reports in the literature, we performed the present study to introduce the accurate long-term effects of ESWL on renal function in the pediatric population.

\section{Study design}

PubMed and Medline were searched for studies on ESWL in the pediatric population with keywords including efficacy, child, kidney calculi, ureter calculi, lithotripsy, injury, vascular trauma, and shock waves. The research was limited to English-language literature from 1980 to 2014. In total, 3,000 articles were evaluated but only 151 papers were considered. Only the manuscripts directly related to the reviewed subjects were included in the current study.

\section{Current indications for SWL}

\section{and success rate}

ESWL is the preferred treatment for small upper urinary tract calculi smaller than $20 \mathrm{~mm}$ in children because of its ease of application and efficacy. ${ }^{13,14}$ More effective disintegration of even larger stones, together with swifter and uncomplicated discharge of larger fragments, can be achieved in children by ESWL. As a consequence, ESWL can be indicated in children with a larger stone volume, and the placement of a ureteral stent before or after ESWL is generally unnecessary. ${ }^{14}$ The stone-free rate of ESWL in children is between $37 \%$ and $52 \%$ in the short-term. ${ }^{15}$ In the long-term, these rates increase to $57 \%$ and $100 \% .{ }^{16}$ However, stone clearance rate by ESWL in children is easier than in adults, and clinicians should be aware of this on acute complications. ${ }^{17}$

\section{Technical aspects of ESWL in children}

The patient should be evaluated, in detail, before treatment. Kidney ureter and bladder X-ray, intravenous pyelography, or computed tomography should be checked for targeted stones. Children must not have a urinary tract infection or coagulation defect before or during ESWL.
An ESWL session take approximately half an hour and focuses on the stone in a supine position. The patient should not move during ESWL. When the child is not old enough to understand our instructions, general anesthesia is needed (1.5 $\mathrm{mg} / \mathrm{kg}$ ketamine and $0.05 \mathrm{mg} / \mathrm{kg}$ midazolam are preferred). ${ }^{18}$ Small children also may need some suspension under the body, and the water cushion also should be adjusted.

The power of the shock wave should be started from the lowest level $(14 \mathrm{kV})$ and may be escalated to the maximum level $(20 \mathrm{kV})$ until fragmentation is observed in fluoroscopy. The number of shock waves should be limited to either the fragmentation observed or a maximum of 1,000 waves per session for children younger than 5 years and to fragmentation or a maximum of 2,500 waves per session for older children. Pulse frequency may be 70 pulses per minute.

After the procedure, patients should be kept under observation until they awaken. Analgesics are usually prescribed when the patient is discharged. It is very important to inform parents about possible hematuria and stone fragments during micturition. In addition, parents should be alert to fever and colic pain.

After ESWL treatments, ultrasonography and/or kidney ureter and bladder X-ray can be used for follow-up. Retreatment by ESWL may be used in case the residual stone size was larger than $4 \mathrm{~mm}$. A maximum of 3 sessions should be performed. When the stone is not fragmented, the other treatment modalities come into question, such as percutaneous nephrolithotomy. ${ }^{19}$

\section{Acute effects of ESWL}

The acute effects of ESWL are well-defined in the literature. ${ }^{7}$ The acute trauma is localized in the area of the stone. More injures are inevitable inside than outside the kidney. It is expected that all children will have hematuria after ESWL. Detailed morphological studies in animals showed that ESWL can rupture blood vessels and can damage the surrounding renal tubules. ${ }^{20,21}$ In these studies, the researchers found that there were torn vessels with platelet aggregation and from vacuolization to complete necrosis of the endothelium. Damaged renal corpuscles in the Bowman capsule and damage to mesangial cells also could be seen. Renal tubules contained blood cell casts, and tubular epithelial cells could show characteristics of ischemia. Kaude et al reported hematomas in $29 \%$ of the patients after ESWL in magnetic resonance imaging. ${ }^{22}$ In addition, there have been some published reports on severe acute injury of ESWL in kidney, such as subcapsular or perineal bleeding. ${ }^{23,24}$ However, these acute complications can be formed after 
ESWL, and Krishnamurthi and Streem reported that most hematomas can resolve within weeks without long-term effects. ${ }^{25}$ Similarly, Aksoy et al reported spontaneous subcapsular hematoma after ESWL in children. ${ }^{26}$ In a recent series, including 128 pediatric ESWL, we reported around $44 \%$ hematuria, with $17.8 \%$ complications. ${ }^{17}$ However, hematuria disappeared up to 1 week after ESWL, and most serious complications were in children with metabolic disorders.

In contrast, when there is a problem focusing on the stone, there can be some adverse effects, such as colon perforation, rupture in hepatic artery, hepatic hematoma, pneumothorax, rupture of spleen, acute necrotizing pancreatitis, urinothorax, and rupture of abdominal aorta. ${ }^{27-35}$

In summary, ESWL may lead to some acute effects in and around the kidney, but these are usually temporary, without long-term effects. In addition, to avoid extreme adverse effects, clinicians should be alert to complications, and they should not miss the focused stones during ESWL. The acute adverse effects of ESWL are shown in Table 1.

\section{Possible adverse effects of ESWL in long-term animal studies}

To date, there has not been performed any study that can fully show the long-term effects of ESWL on kidney. Newman et al reported dose-dependent renal parenchymal fibrosis in dogs, ${ }^{20}$ and this formation was also proven in rabbits by Morris et al. ${ }^{36}$

Lifshitz et al reported that alterations of growth rate in pediatric kidneys treated with ESWL were detected, but the real reasons for this were unknown, ${ }^{37}$ and Claro et al reported that there was no long-term effect on renal function on growing kidneys of younger immature rats after ESWL. ${ }^{38}$

\section{Clinical observation}

Despite there being some suspicious long-term clinical effects of ESWL in adults, Fayad et al reported that ESWL had no adverse effect on the kidney of growing children. ${ }^{18}$ They

Table I Acute effects of extracorporeal shock wave lithotripsy

\section{Effect}

Focal hemorrhage

Rupture of small veins

Extravasation and pooling of blood

Necrosis in vascular wall

Disintegration in podocytes and mesangial cells

Blood within Bowman's space and renal tubules

Ischemic changes

Infiltration by inflammatory cells performed renal scintigraphy with dimercapto-succinic acid and GFR 6 months after ESWL. There were no significant differences in GFR and no renal scar in dimercapto-succinic acid. Vlajković et al also reported no significant changes in GFR in the kidneys of growing children. ${ }^{39}$ Griffin et al reported their 20 years of experience on ESWL in pediatric stone disease and concluded that ESWL did not seem to cause long-term alterations in renal function or the development of permanent renal scars. ${ }^{40}$

In addition, McCullough et al reported that although microscopic hemorrhages were seen in the ovaries examined immediately after shock wave treatment, the number of follicles did not change in female young rats. ${ }^{41}$

In contrast, in the published literature, ESWL had some adverse effects in adults in the long-term. Krambeck et al reported an increased risk for diabetes mellitus and hypertension (HTN) after ESWL in the long-term, ${ }^{42}$ but El-Nahas et al criticize them for performing their long-term follow-up by mailed questionnaire and because there was no comparison with a normal population to estimate the relative risks. ${ }^{43} \mathrm{As}$ El Nahas et al reported, the Mayo Clinic team found that ESWL was not associated with diabetes mellitus ${ }^{44}$ and $\mathrm{HTN}^{45}$ in the long-term. ${ }^{43}$

Frick et al reported HTN after ESWL in children with polycystic kidneys in the long-term. ${ }^{46}$ This was in line with the results of Krambeck et al; ${ }^{42}$ however, it was in contrast to El Nahas et al. ${ }^{45}$ It seems there is need to perform multicenter, long follow-up studies to accurately investigate the long-term effects of EWSL for HTN in children.

In summary, it seems ESWL does not affect kidney functions in the growing kidneys of children in the long-term.

\section{Increasing the effectiveness of ESWL without adverse effects}

Experimental studies showed that renal injury in ESWL is dependent on the number of shock waves, rate of shock delivery, and power setting of the lithotripter. ${ }^{47-50}$ McAteer and Evan suggested that 30 shock waves in a minute had dramatic protective effects on kidney. ${ }^{7}$

In addition, some comorbidities may increase injury after ESWL, such as having a coagulation defect. ${ }^{51,52}$

Lithotripters come into question in the discussion of the effectiveness of devices. Pishchalnikov et al reported the assessments of renal injury by a LithoGold LG-380 (MTS Europe GmbH, Konstanz, Germany) lithotripter in an animal study, and they reported minimum acute injury. ${ }^{53}$ Connors et al reported a low injury effect of MODULITH ${ }^{\circledR}$ SLX (Karl Storz Lithotripsy-America, Inc., Kennesaw, GA, 
USA) in an experimental study. ${ }^{54}$ These findings are important, particularly with regard to children. Thus, more studies for improving the less-acute effective ESWL devices have been needed.

Urinary stone management can be easily performed by ESWL; the indications were discussed earlier. The other treatment options for kidney stones are percutaneous removal and open surgery. ${ }^{13}$ The complex stones and children who do not benefit from ESWL can undergo percutaneous endoscopic surgery. European guidelines on pediatrics suggested that young age with large stones and orthopedic deformities that limit positioning for endoscopic surgery are some of the indications for open surgery. ${ }^{13}$ Nevertheless, most of the stones can be managed by ESWL in childhood.

\section{Conclusion}

ESWL is safe and curative for urolithiasis in children, but there is no doubt that ESWL can lead to acute kidney injury. According to the literature, there is no proven truth about long-term adverse effects of ESWL in the growing kidneys of children. However, ESWL did not seem guilty of kidney damage in children in the long-term, and there is a need for more multicentered studies on this issue.

\section{Disclosure}

The authors report no conflicts of interest in this work.

\section{References}

1. Chaussy C, Schüller J, Schmiedt E, Brandl H, Jocham D, Liedl B. Extracorporeal shock-wave lithotripsy (ESWL) for treatment of urolithiasis. Urology. 1984;23(5 Spec No):59-66.

2. Newman DM, Coury T, Lingeman JE, et al. Extracorporeal shock wave lithotripsy experience in children. $J$ Urol. 1986;136(1 Pt 2):238-240.

3. Cohen TD, Ehreth J, King LR, Preminger GM. Pediatric urolithiasis: medical and surgical management. Urology. 1996;47(3):292-303.

4. Sarica K. Pediatric urolithiasis: etiology, specific pathogenesis and medical treatment. Urol Res. 2006;34(2):96-101.

5. Skolarikos A, Alivizatos G, de la Rosette J. Extracorporeal shock wave lithotripsy 25 years later: complications and their prevention. Eur Urol. 2006;50(5):981-990.

6. Sun BY, Lee YH, Jiaan BP, Chen KK, Chang LS, Chen KT. Recurrence rate and risk factors for urinary calculi after extracorporeal shock wave lithotripsy. J Urol. 1996;156(3):903-905.

7. McAteer JA, Evan AP. The acute and long-term adverse effects of shock wave lithotripsy. Semin Nephrol. 2008;28(2):200-213.

8. Kaji DM, Xie HW, Hardy BE, Sherrod A, Huffman JL. The effects of extracorporeal shock wave lithotripsy on renal growth, function and arterial blood pressure in an animal model. J Urol. 1991; 146(2(Pt 2)):544-547.

9. Cimentepe E, Eroglu M, Oztürk U, et al. Rapid communication: renal apoptosis after shockwave application in rabbit model. $J$ Endourol. 2006;20(12):1091-1095.

10. Lottmann HB, Archambaud F, Traxer O, Mercier-Pageyral B, Helal B. The efficacy and parenchymal consequences of extracorporeal shock wave lithotripsy in infants. BJU Int. 2000;85(3):311-315.
11. Goel MC, Baserge NS, Babu RV, Sinha S, Kapoor R. Pediatric kidney: functional outcome after extracorporeal shock wave lithotripsy. J Urol. 1996;155(6):2044-2046.

12. Dogan HS, Tekgul S. Management of pediatric stone disease. Curr Urol Rep. 2007;8(2):163-173.

13. Tekgül S, Riedmiller H, Dogan HS. Guidelines on Paediatric Urology. Arnheim, The Netherlands: European Association of Urology; 2013. Available from: http://www.uroweb.org/gls/pdf/22\%20Paediatric $\% 20$ Urology_LR.pdf. Accessed February 4, 2014.

14. Gnessin E, Chertin L, Chertin B. Current management of paediatric urolithiasis. Pediatr Surg Int. 2012;28(7):659-665.

15. Brinkmann OA, Griehl A, Kuwertz-Bröking E, Bulla M, Hertle L. Extracorporeal shock wave lithotripsy in children. Efficacy, complications and long-term follow-up. Eur Urol. 2001;39(5):591-597.

16. Muslumanoglu AY, Tefekli A, Sarilar O, Binbay M, Altunrende F, Ozkuvanci U. Extracorporeal shock wave lithotripsy as first line treatment alternative for urinary tract stones in children: a large scale retrospective analysis. $J$ Urol. 2003;170(6 Pt 1):2405-2408.

17. Yucel S, Akin Y, Danisman A, Guntekin E. Complications and associated factors of pediatric extracorporeal shock wave lithotripsy. J Urol. 2012;187(5):1812-1816.

18. Fayad A, El-Sheikh MG, Abdelmohsen M, Abdelraouf H. Evaluation of renal function in children undergoing extracorporeal shock wave lithotripsy. J Urol. 2010;184(3):1111-1114.

19. Bilen CY, Gunay M, Ozden E, Inci K, Sarikaya S, Tekgul S. Tubeless mini percutaneous nephrolithotomy in infants and preschool children: a preliminary report. U Urol. 2010;184(6):2498-2502.

20. Newman R, Hackett R, Senior D, et al. Pathologic effects of ESWL on canine renal tissue. Urology. 1987;29(2):194-200.

21. Shao Y, Connors BA, Evan AP, Willis LR, Lifshitz DA, Lingeman JE. Morphological changes induced in the pig kidney by extracorporeal shock wave lithotripsy: nephron injury. Anat Rec A Discov Mol Cell Evol Biol. 2003;275(1):979-989.

22. Kaude JV, Williams CM, Millner MR, Scott KN, Finlayson B. Renal morphology and function immediately after extracorporeal shock-wave lithotripsy. AJR Am J Roentgenol. 1985;145(2):305-313.

23. Baskin LS, Stoller ML. Severe haemorrhage after extracorporeal shock wave lithotripsy: radiological evaluation. Br J Urol. 1992;69(2): 214-215.

24. Maziak DE, Ralph-Edwards A, Deitel M, Wait J, Watt HJ, Marcuzzi A. Massive perirenal and intra-abdominal bleeding after shock-wave lithotripsy: case report. Can J Surg. 1994;37(4):329-332.

25. Krishnamurthi V, Streem SB. Long-term radiographic and functional outcome of extracorporeal shock wave lithotripsy induced perirenal hematomas. J Urol. 1995;154(5):1673-1675.

26. Aksoy Y, Ozbey I, Atmaca AF, Polat O. Extracorporeal shock wave lithotripsy in children: experience using a mpl-9000 lithotriptor. World J Urol. 2004;22(2):115-119.

27. Castillon I, Frieyro O, Gonzalez-Enguita C, Vela-Navarrete R. Colonic perforation after extracorporeal shock wave lithotripsy. BJU Int. 1999;83(6):720-721.

28. Beatrice J, Strebel RT, Pfammatter T, Röhweder JH, Sulser T. Life-threatening complication after right renal extracorporeal shock wave lithotripsy: large hepatic haematoma requiring embolisation of the right hepatic artery. Eur Urol. 2007;52(3):909-911.

29. Fugita OE, Trigo-Rocha F, Mitre AI, Arap S. Splenic rupture and abscess after extracorporeal shock wave lithotripsy. Urology. 1998;52(2):322-323.

30. Karakayali F, Sevmiş S, Ayvaz I, Tekin I, Boyvat F, Moray G. Acute necrotizing pancreatitis as a rare complication of extracorporeal shock wave lithotripsy. Int J Urol. 2006;13(5):613-615.

31. Hassan I, Zietlow SP. Acute pancreatitis after extracorporeal shock wave lithotripsy for a renal calculus. Urology. 2002;60(6):1111.

32. Oğuzülgen IK, Oğuzülgen AI, Sinik Z, Köktürk O, Ekim N, Karaoğlan U. An unusual cause of urinothorax. Respiration. 2002; 169(3):273-274. 
33. Neri E, Capannini G, Diciolla F, et al. Localized dissection and delayed rupture of the abdominal aorta after extracorporeal shock wave lithotripsy. J Vasc Surg. 2000;31(5):1052-1055.

34. Tiede JM, Lumpkin EN, Wass CT, Long TR. Hemoptysis following extracorporeal shock wave lithotripsy: a case of lithotripsy-induced pulmonary contusion in a pediatric patient. J Clin Anesth. 2003;15(7): $530-533$

35. Meyer JJ, Cass AS. Subcapsular hematoma of the liver after renal extracorporeal shock wave lithotripsy. J Urol. 1995;154(2 Pt 1): 516-517.

36. Morris JS, Husmann DA, Wilson WT, Preminger GM. Temporal effects of shock wave lithotripsy. J Urol. 1991;145(4):881-883.

37. Lifshitz DA, Lingeman JE, Zafar FS, Hollensbe DW, Nyhuis AW, Evan AP. Alterations in predicted growth rates of pediatric kidneys treated with extracorporeal shockwave lithotripsy. J Endourol. 1998; 12(5):469-475.

38. Claro Jde A, Denardi F, Ferreira U, Rodrigues Netto N Jr, Saldanha LB, Figueiredo JF. Effects of extracorporeal shockwave lithotripsy on renal growth and function: an animal model. J Endourol. 1994;8(3) 191-194.

39. Vlajković M, Slavković A, Radovanović M, Sirić Z, Stefanović V, Perović S. Long-term functional outcome of kidneys in children with urolithiasis after ESWL treatment. Eur J Pediatr Surg. 2002;12(2): $118-123$.

40. Griffin SJ, Margaryan M, Archambaud F, Sergent-Alaoui A, Lottmann HB. Safety of shock wave lithotripsy for treatment of pediatric urolithiasis: 20-year experience. J Urol. 2010;183(6):2332-2336.

41. McCullough DL, Yeaman LD, Bo WJ, et al. Effects of shock waves on the rat ovary. J Urol. 1989;141(3):666-669.

42. Krambeck AE, Gettman MT, Rohlinger AL, Lohse CM, Patterson DE, Segura JW. Diabetes mellitus and hypertension associated with shock wave lithotripsy of renal and proximal ureteral stones at 19 years of followup. J Urol. 2006;175(5):1742-1747.

43. El-Nahas AR, Awad BA, El-Assmy AM, et al. Are there long-term effects of extracorporeal shockwave lithotripsy in paediatric patients? BJU Int. 2013;111(4):666-671.
44. de Cógáin M, Krambeck AE, Rule AD, et al. Shock wave lithotripsy and diabetes mellitus: a population-based cohort study. Urology. 2012;79(2):298-302.

45. Krambeck AE, Rule AD, Li X, Bergstralh EJ, Gettman MT, Lieske JC. Shock wave lithotripsy is not predictive of hypertension among community stone formers at long-term followup. J Urol. 2011;185(1): 164-169.

46. Frick J, Sarica K, Köhle R, Kunit G. Long-term follow-up after extracorporeal shock wave lithotripsy in children. Eur Urol. 1991;9(3): 225-229.

47. Willis LR, Evan AP, Connors BA, et al. Shockwave lithotripsy: dose-related effects on renal structure, hemodynamics, and tubular function. J Endourol. 2005;19(1):90-101.

48. Connors BA, Evan AP, Blomgren PM, et al. Reducing shock number dramatically decreases lesion size in a juvenile kidney model. J Endourol. 2006;20(9):607-611.

49. Connors BA, Evan AP, Willis LR, Blomgren PM, Lingeman JE, Fineberg NS. The effect of discharge voltage on renal injury and impairment caused by lithotripsy in the pig. J Am Soc Nephrol. 2000;11(2) 310-318.

50. Delius M, Enders G, Xuan ZR, Liebich HG, Brendel W. Biological effects of shock waves: kidney damage by shock waves in dogs - dose dependence. Ultrasound Med Biol. 1981;4(2):117-122.

51. Newman LH, Saltzman B. Identifying risk factors in development of clinically significant post-shock-wave lithotripsy subcapsular hematomas. Urology. 1991;38(1):35-38.

52. Ozgür BC, Irkilata L, Ekici M, et al. Pediatric extracorporeal shock wave lithotripsy: Multi-institutional results. Urologia. Epub February 26, 2014.

53. Pishchalnikov YA, McAteer JA, Williams JC Jr, et al. Evaluation of the LithoGold LG-380 lithotripter: in vitro acoustic characterization and assessment of renal injury in the pig model. J Endourol. 2013;27(5): 631-639.

54. Connors BA, McAteer JA, Evan AP, et al. Evaluation of shock wave lithotripsy injury in the pig using a narrow focal zone lithotriptor. $B J U$ Int. 2012;110(9):1376-1385.
Research and Reports in Urology

\section{Publish your work in this journal}

Research and Reports in Urology is an international, peer-reviewed, open access journal publishing original research, reports, editorials, reviews and commentaries on all aspects of adult and pediatric urology in the clinic and laboratory including the following topics: Pathology, pathophysiology of urological disease; Investigation and treatment of

\section{Dovepress}

urological disease; Pharmacology of drugs used for the treatment of urological disease. The manuscript management system is completely online and includes a very quick and fair peer-review system, which is all easy to use. Visit http://www.dovepress.com/testimonials.php to read real quotes from published authors. 